\title{
Early detection of cardiac iron deposition in patients with thallassemia, what is the best strategy?
}

\author{
L. H. B. Baur
}

Received: 17 July 2008/Accepted: 17 July 2008/Published online: 12 August 2008

(C) The Author(s) 2008

$\beta$-Thallassemia is an inherited disorder of haemoglobin synthesis, resulting in chronic haemolytic anemia. Adequate blood transfusions and continuous chelation therapy are the milestones of treatment. In adults, the major haemoglobin is haemoglobin A, a tetramer consisting of one pair of $\alpha$ chains and one pair of $\beta$ chains. Normally the ratio of $\alpha$ to $\beta$ chains is one. In patients with thallassemia production of $\beta$ chains is diminished. The excess $\alpha$ chains are unstable and incapable of forming soluble teramers. These chains precipitate in the cell, leading to a variety of clinical manifestations [1]. Thallassemias arise from over 100 mutations, that affect every step for production of normal haemoglobin. The frequency for genetic abnormalities associated with $\beta$-thallassemia approaches 0.1 in South Mediterranean areas in Europe. Both sexes are equally affected [2]. The $\beta$ thallassemia syndromes are remarkable for their heterogeneity and clinical expression of the genetic abnormality [3]. Patients with a $\beta$-thallassemia mutation on each chromosome usually exhibit some degree of $\alpha$-globin inclusion body formation, with

L. H. B. Baur $(\square)$

Department of Cardiology, Atrium Medical Centre

Parkstad, University of Maastricht, Maastricht,

The Netherlands

e-mail: lbr01@atriummc.nl

\section{H. B. Baur}

Department of Cardiology, University of Maastricht, Henri Dunantstreet 5, Heerlen, 6401 CX, The Netherlands consequent anemia, hemolysis and varying degrees of ineffective erythropoiesis [1]. The clinical syndrome associated with this genetic disorder is called thallassemia major. Patients, who are heterozygotes for $\beta$-thallassemia are mostly asymptomatic. This, because the erythrocyte is able to catabolize some of the excess unpaired $\alpha$-globulin chains [1]. The syndrome is usually described as thallassemia minor or thallassemia intermediate. In patients with $\beta$-thallassemia major cardiac abnormalities occur frequently next to disorders of the liver and spleen, skeletal abnormalities and kidney and endocrine abnormalities [4]. Heart failure and rhythm disturbances are the main cause of death in adults with thallassemia major. In a recently published multicenter study $5 \%$ of patients aged 16-24 years and 23\% of patients older than 25 years had heart disease requiring medication [5]. In another study congestive heart failure was observed in $5.4 \%$ of patients with thallassemia intermedia. Eight percent of these patients had a history of acute pericarditis [4]. The most prominent finding in patients with thallassemia major is left ventricular dysfunction, which is mainly due to severe anemia and iron overload because of the regular blood transfusions required to avoid hypoxia [6].

The estimation of iron stores in the heart would be very helpful in order to evaluate the efficacy of chelation therapy and determine the cardiac risk. Although the iron storage proteins like hemosiderin and ferritin are mostly intracellular, serum ferritin is highly correlated with the amount of iron deposition 
and can therefore used as an index for intracardiac iron load [7]. However, ferritin levels can be affected by factors as fever or inflammation [8].

Therefore non-invasive guidance of cardiac iron loading with $\mathrm{T} 2 *$ magnetic resonance imaging is a better technique evaluate chelation therapy in patients with thallassemia major [9].

Iron deposition results in shortening of proton relaxation times, which can be used to assess myocardial iron overload [10]. T2 relaxation time has a linear correlation with the total iron content in the heart [11] The current paper of Mavrogeni et al. shows, that $\mathrm{T} 2 *$ imaging is able to differentiate between thallassemia major and thallassemia intermediate [12]. The $\mathrm{T} 2 *$ values of patients with thallassemia major were half the value of patients with thallassemia intermediate and normal individuals. Also right and left ventricular volumes and right and left ventricular ejection fraction were higher in the thallassemia intermediate patients compared to the patients with thallassemia major. This despite equal ferritin levels in both groups. These findings are important, because the current study of Mavrogeni et al. shows, that MRI with T2* imaging is a far more sensitive technique to detect cardiac iron load than measurement of serum ferritin. Although echocardiography with tissue velocity imaging is able to detect early ventricular function and ventricular dilation in thallassemia patients it does not detect cardiac iron load [13].

Therefore cardiac magnetic resonance imaging is the preferred technique to image iron load in the myocardium in patients with thallassemia and guide chelation therapy.

Open Access This article is distributed under the terms of the Creative Commons Attribution Noncommercial License which permits any noncommercial use, distribution, and reproduction in any medium, provided the original author(s) and source are credited.

\section{References}

1. Benz EJ, Schrier S, Landaw SA (2008) Clinical manifestations of the thalassemias UpToDate 16.1
2. Mavrogeni SI, Maris T, Gouliamos A, Vlahos L, Kremastinos DT (1998) Myocardial iron deposition in $\beta$ thallassemia studied by magnetic resonance imaging. Int $\mathrm{J}$ Cardiovasc Imaging 14:117-122

3. Bunn HF, Forget BG (1986) Hemoglobin: Molecular genetic and clinical aspects. WB Saunders, Philadelphia

4. Aessopos A, Farmakis D, Karagiorga M, Voskaridou E, Loutradi A, Hatziliami A, Joussef J, Rombos J, Loukopoulos D (2001) Cardiac involvement in thallassemia intermedia: a multicenter study. Blood 97:3411-3416

5. Cunningham MJ, Macklin EA, Neufeld EJ, Cohen AR (2004) Complications of $\beta$-thallassemia major in North America. Blood 104:34-39

6. Ehlers KH, Levin AR, Markenson AL, Marcus JR, Klein AA, Levin AR, Subramanian VA (1980) Longitudinal study of cardiac function in thallasemia major. Ann N Y Acad Sci 344:397-404

7. Jacobs A, Miller F, Worwood M, Beamisch R, Wardrop C (1972) Ferritin in the serum of normal subjects with iron deficiency and iron overload. Br Med J 4:206-211

8. Crosby WH (1976) Serum ferritin fails to indicate hemochromatosis: nothing gold cab stay. N Engl J Med 294: 333-334

9. Tanner MA, Galanello R, Dessi C, Smith GC, Westwood MA, Agus A, Pibiri M, Nair SV, Walker JM, Pennell DJ (2008) Combined chelation therapy in thallassemia major for the treatment of severe myocardial siderosis with left ventricular dysfunction. J Cardiov Magn Reson 10:12

10. Anderson LJ, Westwood MA, Holden S, Davis B, Prescott E, Wonke B, Porter JB, Walker JM, Pennell DJ (2004) Myocardial iron clearance during reversal of siderotic cardiomyopathy with intravenous desferrioxamine: A prospective study using T2* cardiovascular magnetic resonance. Br J Haematol 127:348-355

11. Brittenham GM, Badman DG (2003) Noninvasive measurement of iron: report of a NIDDK workshop. Blood 101:15-19

12. Mavrogeni SI, Gotsis E, Ladis V, Berdousis E, Verganelakis D, Toulas P, Cokkinos DV (2008) Magnetic resonance evaluation of liver and myocardial iron deposition in thallassemia intermediate and b-thallassemia major. Int J Cardiovasc Imaging. doi:10.1007/s10554-008-9332-2

13. Hamdy AM (2007) Use of strain and tissue velocity imaging for early detection of regional myocardial dysfunction in patients with beta thallassemia. Eur J Echocardiogr 8:102-109 